\title{
Decent work and development policies
}

Gary S. FIELDS*

$T^{1}$

he International Labour Organization's guiding principle is the promotion of social justice and internationally recognized human and labour rights. Ever since its founding in 1919, the Organization has sought to "improve the situation of human beings in the world of work" (ILO, 1999, p. 3). It seeks to position itself as "the global reference point for knowledge on employment and labour issues; the centre for normative action in the world of work; a platform for international debate and negotiation on social policy; and a source of services for advocacy, information and policy formulation" (ibid., p. 2).

In 1999, the ILO set itself a new goal: "Decent Work for All", which aims to secure decent work for women and men everywhere. The objective is the creation of not just jobs, but jobs of acceptable quality. This is pursued through four strategic objectives: full employment, improved levels of socio-economic security, universal respect for fundamental principles and rights at work, and the strengthening of social dialogue (ibid.).

Decent work is a new and welcome way of achieving the ILO's historic task, for it has shifted the focus to outcomes: what kinds of work people are doing, how remunerative and secure this work is, and what rights workers enjoy in the workplace. This redirection of ILO energies raises a new set of issues.

The first task is to render the notion of decent work more precise in operational terms. Accordingly, decent work is set in the context of core labour standards including full employment, but it goes beyond that to include the returns from employment as well.

The second task is to develop an integrated approach to economic and social policy in the context of decent work, as requested by the Working Party on the Social Dimension of Globalization in November

* Department of Labor Economics, School of Industrial and Labor Relations, Cornell University, Ithaca, NY. This article is the revised version of a paper prepared for the ILO's International Policy Group, in March 2001. 
2000 (ILO, 2000a). To some, economic and social policies are distinct entities. In my view, however, this is a false dichotomy. Rather, economic policy and social policy are both development policies - as is decent work. They all share a common purpose: improving people's economic and social well-being through economic development. Wise policies cannot be formulated until it is known what a given country is trying to achieve. The concept of decent work helps specify the development objective.

The third task is to formulate an empirical approach for assessing the effects of economic growth on decent work in today's globalized world. Observers differ in their views on this matter. Some contend that economic growth creates more jobs and improves conditions for those already employed. On this first view, economic growth and improved employment conditions go hand in hand. Others contend just the opposite: that in today's globalized world, wages and other labour costs must be held down in order to maintain existing markets and penetrate new ones. On this second view, economic growth and decent work are competing objectives. This article will discuss the kinds of data that might be brought to bear to adjudicate between these views, and to present the results of prior studies on this subject.

The fourth task is to outline the structure of subsequent country reviews. The ILO plans country-by-country assessments of progress towards decent work. This article suggests what might be highlighted in these reviews of country experiences and policies. A structure is proposed, comprising three key data needs and three key policy areas. The factual areas are changes over time in:

employment and unemployment;

job mix; and

earnings levels.

The policy areas are:

- labour demand and policies that affect private sector and public sector job creation;

- labour supply and policies that affect the quantity and quality of available labour resources; and

- labour market functioning - in particular, market and non-market institutions that determine wages, non-wage benefits, and other ways in which demand and supply intersect.

The main points are then highlighted in a brief conclusion.

\section{Operationalizing decent work for policy purposes}

Three elements are essential to the achievement of decent work objectives: the need for jobs, the honouring of core labour standards, and 
the pursuit of further improvements in job quality. Because beyond some point the achievement of one of these objectives may come at the expense of another, the idea of a "decent work frontier" is also formulated.

\section{The need for jobs}

The first element of decent work is employment. It is a truism, but nonetheless true, that for a person to have a decent job, he or she must have a job. Study after study reports that jobs are what people want. The need for more jobs is central to the decent work paradigm, and full employment rightfully occupies the prime position at the forefront of the decent work effort.

In circumstances where the economy does not generate enough jobs, supplementary job programmes can make a tremendous difference. A striking illustration is an advertisement taken out in a number of leading magazines by the United Nations' World Food Programme. The advertisement - "The pay's lousy, the conditions terrible, and the workers love it" - speaks eloquently to the vital importance of Food for Work and other such programmes, on which much has been written (e.g., Lipton, 1998).

\section{The core labour standards context}

The second essential ingredient is respect for core labour standards. In the last few years, thinking in the world community has coalesced around a set of core labour standards aimed at promoting and assuring fundamental principles and rights at work. Some major associated events include the World Summit on Social Development, held in Copenhagen in March 1995, which defined core labour standards as including the prohibition of forced labour and child labour, freedom of association and the right to organize and bargain collectively, equal remuneration for men and women for work of equal value, and non-discrimination in employment. Also influential in establishing agreement on core labour standards was a study published by the Organisation for Economic Co-operation and Development (OECD) in 1996, which called for freedom of association and the right to collective bargaining, elimination of exploitative forms of child labour, the prohibition of forced labour, and non-discrimination in employment (OECD, 1996). Then, at their Ministerial Conference in Singapore in December 1996, the member States of the World Trade Organization (WTO) restated their commitment to internationally recognized core labour standards, supported collaboration between the secretariats of the WTO and ILO, rejected the use of labour standards for protectionist purposes, and recognized the ILO as the competent body for dealing with this issue. The Chairman of the Conference, Yeo Cheow Tong, 
Singapore's Minister of Trade and Industry, further emphasized what the text of the ministerial declaration did not make explicit: "It does not inscribe the relationship between trade and core labour standards on the WTO agenda.... There is no authorization in the text for any new work on this issue" (WTO, 1997, p. 14).

A key defining moment following these developments was when the International Labour Conference approved a historical document, the ILO Declaration on Fundamental Principles and Rights at Work, at its 86th Session in June 1998. The Declaration affirms that all ILO member States (now 176 in number) have the responsibility "to respect, to promote and to realize, in good faith and in accordance with the Constitution [of the ILO], the principles concerning the fundamental rights", which include:

(a) freedom of association and the effective recognition of the right to collective bargaining;

(b) the elimination of all forms of forced or compulsory labour;

(c) the effective abolition of child labour; and

(d) the elimination of discrimination in respect of employment and occupation.

Subsequently, the Secretary-General of the United Nations, Kofi Annan, integrated these four core labour standards into the nine-point Global Compact of shared values and principles concerning human rights, labour and the environment, which was launched in January 1999. The Global Compact has been endorsed by business groups, individual companies, organized labour, and non-governmental organizations. In August 2000, the 33 adhering countries of the OECD incorporated these core labour standards into their revised $O E C D$ Guidelines for multinational enterprises: Global instruments for corporate responsibility (OECD, 2000a). Ongoing efforts to redress the "decent work deficit" are highlighted in the Report of the DirectorGeneral to the International Labour Conference, 89th Session, June 2001 (ILO, 2001a).

Jobs in which these core labour standards are not respected cannot be regarded as decent. In fact, they can be characterized as indecent work: work in conditions so odious or harmful that it would be better for people not to work at all than to work in such damaging conditions.

The decision to oppose indecent work entails a judgement about what would happen to the workers who are displaced if indecent work were banned. It is one thing if they move into such activities as streetvending, petty services, family farms or micro-enterprises. It is quite another if the alternative is prostitution, scavenging in garbage dumps, or worse. The alternatives will vary from place to place and a careful assessment must be made of what they actually constitute. Sadly, it 
must be realized that blanket opposition to alternatives deemed unacceptable may produce harmful results.

\section{Improving the quality of jobs}

Jobs alone are not enough, even those in which core labour standards are respected. The Director-General of the ILO has stated: "The ILO is concerned not only with the creation of jobs, but with the creation of jobs of acceptable quality. The quantity of employment cannot be divorced from its quality" (ILO, 2000b, p. 4).

Which aspects of job quality are the most important? Security, respect, dignity and participation are all important aspects of the workplace. The four core labour standards - freedom of association and collective bargaining, elimination of forced or compulsory labour, an end to child labour and the elimination of discrimination - must be respected if work is to be decent. That is precisely why these standards command so much support in the international community.

Nevertheless, the core labour standards do not suffice. A key job characteristic is missing: the amount the job pays. An estimated 1.3 billion people in the world live on less than US\$ 1 per person per day, and another 1.7 billion live on between US $\$ 1$ and 2 per day. In other words, half of humanity is absolutely poor. Moreover, more than a billion men and women in the world are unemployed, underemployed or working for poverty wages (which the ILO defines as less than US $\$ 1$ per day). About 550 million of these are the working poor (ILO, 2003). Work that provides such low standards of living and such low rewards must be improved.

For, such improvements are what workers want. The World Bank's World Development Report 2000/2001 quotes a young Bulgarian woman as saying, "If you have a job at all now, you're overworked and underpaid" (World Bank, 2000, p. 34). In a similar vein, a Guatemalan worker stated, "Some have land, but they can't buy fertilizer; if some work as weavers, they aren't well paid; if some work for daily wages, they aren't paid a just wage" (ibid., p. 34). So, in the eyes of these people, what is poor-quality work? Above all, it is work that pays badly. This is not to say that the earnings level is the only aspect of quality of work. But in general, and especially for the half of humanity who subsist on less than US\$ 2 per person per day, earnings from work are the best indicator of the goodness or badness of the work they are doing.

Two misunderstandings about international labour standards abound, in both political and popular discussions. First, it is important to be clear that earnings levels are not included in international labour standards as they are now being discussed (cf. above). One important exception, though, is United States trade law, which defines "internationally recognized worker rights" as including "acceptable conditions 
of work with respect to minimum wages, hours of work, and occupational safety and health" (United States Congress, 2002). However, it is because such standards cannot be established and enforced internationally, and because many developing countries are strongly opposed to them, that standards about working conditions are not included as core labour standards in international discussions at present.

Second, although the possibility of trade sanctions against countries not respecting core labour standards is brought up occasionally, the question of sanctions is effectively off the table at the present time. For example, Canada, the European Union and the United States have called for various types of working groups on trade and labour standards in the WTO. Yet, during the meeting of the WTO which attracted such opposition in Seattle in November 1999, and at similar subsequent meetings since, no agreement was reached even on the question of whether to study the issue of trade sanctions against countries that violate core labour standards. Trade sanctions are not being considered in any serious way at present (OECD, 2000b, p. 51; WTO, 2003).

In short, higher labour earnings are not going to be achieved through international labour standards - nor should they be. Higher labour earnings must be sought through indirect means, including economic growth - a topic which will be returned to later.

\section{The "decent work frontier"}

Decent work was described above as incorporating both the quantity and the quality of work in which core labour standards are respected. To operationalize this notion, the quantity of work may be gauged by the volume of employment and the quality of work by the earnings level. The trade-off between quantity and quality of work is embodied in the downward-sloping demand for labour curve that is at the core of labour economics. The downward-sloping labour demand curve portrays the likelihood that, in any given circumstance, the higher the rate of pay, the lower the volume of employment. Labour demand elasticities have been estimated for a great variety of countries using a wide range of methodologies, and these studies always establish the existence of a trade-off between earnings level and employment (Hamermesh, 1993). As long as the labour demand curve is stationary, more work for some necessarily means lower earnings for others, and vice versa. In a very real sense, the downward-sloping labour demand curve in a given labour market represents, at that point in time, a "decent work frontier" (figure 1a).

The decent work frontier must be acknowledged. Even if the choice is limited to employment versus earnings, drawing a fixed labour demand curve focuses attention on labour market conditions as they are, and forces countries to confront difficult choices. Given the limited 
Figure 1a. A given decent work frontier

Quality of work

(earnings per worker)

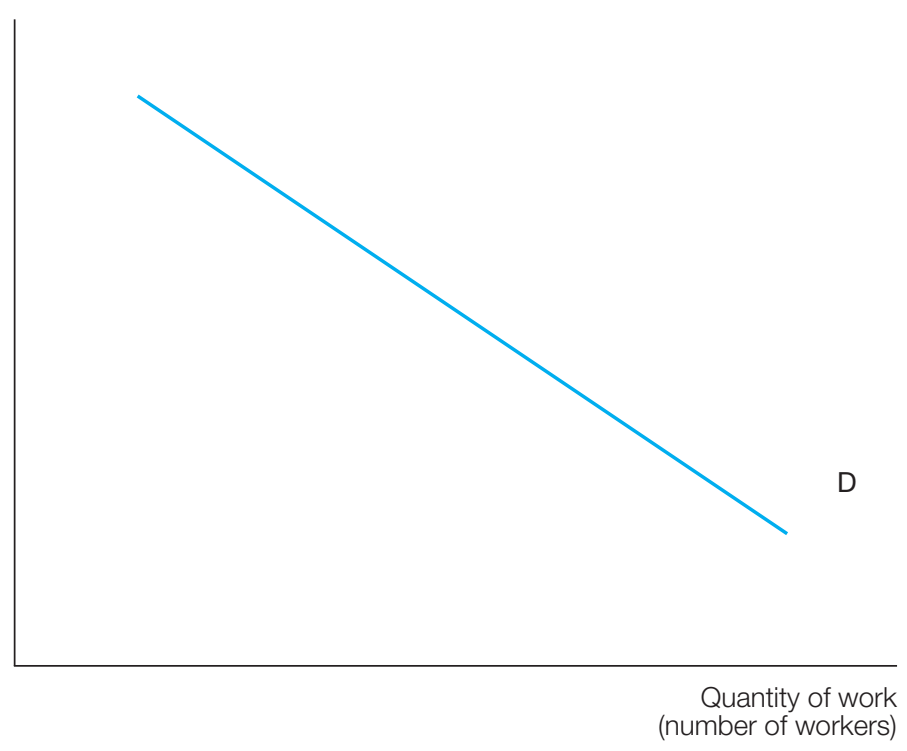

Figure 1b. Shifting the decent work frontier

Quality of work

(earnings per worker)

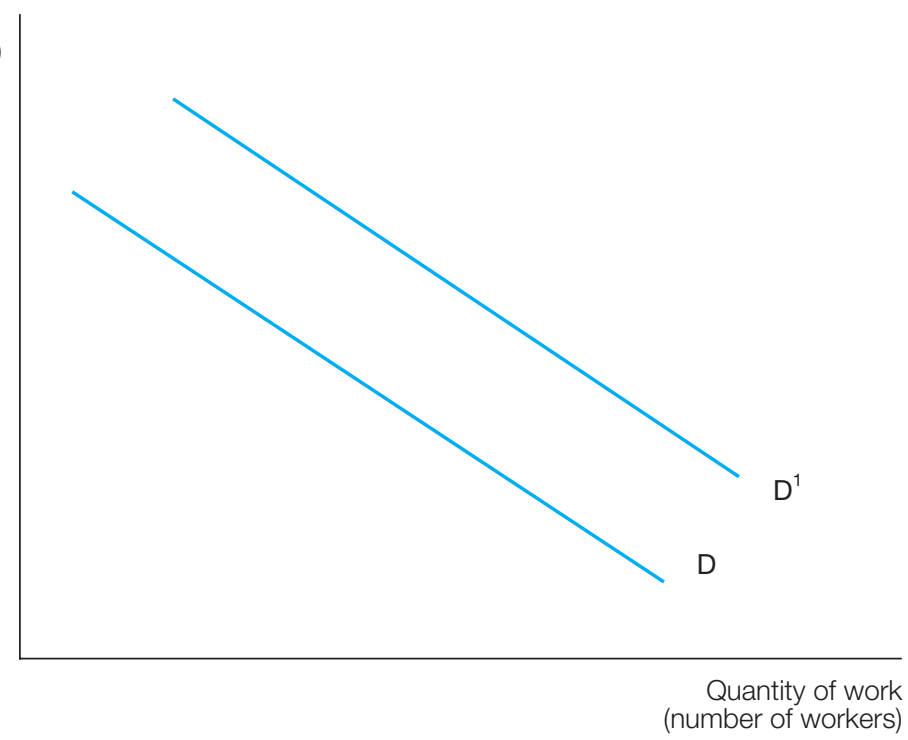


resources at their disposal (and all countries, even the richest, have limited resources), do policy-makers wish to deploy those resources to raise the earnings of those already employed or to increase the employment of those not now working but wishing to work? Or, if the terms of decent work were broadened, should governments use those scarce resources to strengthen economic security programmes in the workplace, enforce rights and facilitate social dialogue? Priorities must be set - an issue which will be returned to later. For now, let us recognize that there are opportunity costs: the time, money and energy used to promote one of these goals are not available to promote another.

By facing the trade-off between employment and earnings along a given labour demand curve, it may be seen that decent work can be enhanced if ways can be found to shift the demand curve for labour rightward, so that more labour will be demanded than before at any given earnings level (figure 1b). Such a shift would make it possible to increase both employment and earnings at the same time. This would be a very happy outcome, and is indeed what many countries have achieved.

This, then, provides a precise way of formulating the public policy goal of advancing the decent work agenda: to shift the labour demand curve rightward as fast as possible. To the extent that this can be done, countries will be able to achieve more employment at a given level of earnings, higher earnings for a given level of employment, or some of each. One decent work goal (quantity of work) will not have to be achieved at the expense of another (quality of work).

\section{The operationalization of decent work}

To summarize this section, when a man or a woman has no job, he or she certainly lacks decent work. Moreover, work is indecent if core labour standards are not respected, for example, if the work is damaging to the worker's health and safety. It must be asked whether, in such conditions and given the available options, it is better for people not to work at all than to work in such jobs. Finally, some jobs may be decent but are not acceptable: these are jobs in which core labour standards are respected but which pay earnings below the amount needed to enable an average-sized family to attain an internationally agreed minimal standard of living. It follows that decent work is not a single entity or point; rather, it is a frontier.

Even if decent work is proclaimed as the goal, choices still have to be made between moving primarily towards quantity or towards quality. To be able to make these choices, national policy-makers and their advisers must be clear about what they are trying to achieve. Wise choices depend not only on specifying what is to be maximized, but also on what the policy variables are and how the outcome variables of 
interest would be changed if these policy instruments were to be deployed in different ways. Let us turn our attention, therefore, to an analytical framework for bringing such considerations to bear.

\section{Towards an integrated approach to economic and social policy}

\section{Economic policies versus social policies: How useful a distinction?}

What are economic policies, what are social policies and how separate are they? In some people's minds, economic policies include such factors as monetary and fiscal policy, openness to trade, capital market liberalization and establishment of a sound regulatory framework. Social policies, on the other hand, are said to relate to health, education, welfare and distributional concerns. In my view, however, these various policies are part and parcel of the same thing.

In his textbook on Economics, Paul Samuelson famously emphasized that all economies must answer three fundamental questions: What? How? For whom? (Samuelson, 1964). "What?" means that choices have to be made about what goods and services are going to be produced. "How?" means that choices have to be made about what technologies to use and how much labour, capital and other inputs to employ. "For whom?" means that choices have to be made about how to allocate the goods and services that are produced. In no way do Samuelson's fundamental questions restrict economic policy to monetary and fiscal policy, trade and budget deficits and exchange rates and interest rates.

It was also Samuelson who, in that same context, formulated the famous trade-off between guns and butter. Choosing to produce guns or butter is, of course, a metaphor for choosing between public-sector goods and private-sector goods, and likewise for choosing social goods as against personal goods. Allocating goods by a mechanism whereby participants bring their initial earnings and other private incomes to a free market is one, and only one, way of determining "for whom?". Allocating goods in a controlled market, where prices are established by price ceilings and the like, is another. Providing people with supplemental purchasing power, such as food stamps and health insurance cards, is still another. Yet another mechanism is to provide people with goods directly: free food for the poor, free public schools for children, medical care for the elderly, and so on. In all of these cases, how the "for whom?" question is answered helps determine the answer to the "what?" question. Hence, questions that might be called "economic" cannot be answered without also answering questions that might be called "social". 
Another illustration of the connection between economic and social policies may be found in the terms of reference of the Economic and Social Council of the United Nations. These have been summarized as follows:

The Economic and Social Council was established by the Charter [of the United Nations] as the principal organ, under the authority of the General Assembly, to promote: (a) higher standards of living, full employment, and conditions of economic and social progress and development; (b) solutions of international economic, social, health, and related problems; and international cultural and educational cooperation; and (c) universal respect for, and observance of, human rights and fundamental freedoms for all without distinction as to race, sex, language, or religion (Article 55, sub-paragraphs (a), (b) and (c)) (United Nations, 2003, p. 1).

It is impossible to separate the "economic" objectives from the "social" ones in this statement.

One last illustration of the essential intertwining of economic and social policy is the annual United States publication, the Economic Report of the President. The report always includes topics typically considered as "economic" policy - for instance, there is always a chapter on macroeconomic policy and performance. Recent reports have included chapters on capital flows in the global economy, technology and the United States economy, the evolution and reform of the international financial system, regulation and innovation, and the new economy in a global context - "economic" policies, all. But the reports devote even more chapters to what might be called "social" policies: benefits of a strong labour market; work, retirement and the economic well-being of the elderly; making markets work for the environment; the changing American family; strengthening retirement security; promoting health care quality and access; building institutions for a better environment; and corporate governance and its reform. To the President of the United States and his Council of Economic Advisers, these "social" policies are "economic" too - otherwise, they would not belong in an economic report of the President.

These examples illustrate that a well-established tradition in economics and other social sciences treats economic and social policies as linked. The challenge is to carry out policy analysis with these dual perspectives at the forefront. The remainder of this section will suggest how this might be done.

\section{A welfare economic approach to decent work}

Welfare economics is the branch of economics that deals with social well-being. One or more criteria are set forth as defining the goodness or badness of a country's social state. Criteria commonly used for this purpose are growth in gross domestic product (GDP), unemployment, inequality and poverty. The question is then asked: a given 
action is undertaken, how do each of these components change? If a contemplated policy would raise GDP growth while lowering unemployment, inequality and poverty, most analysts would regard such a change as a good thing. It is in this sense that welfare economics enables analysts to reach policy conclusions of a conditional nature: in some circumstances, all who adopt a particular set of social valuations would favour a policy, because those social conditions judged to be good are raised while those judged to be bad are diminished. To the extent possible, then, public policy would pursue such "good" policies and, in so doing, attain the highest possible social welfare.

One problem is that, for many economic policies, it is by no means clear what is being maximized. What is the purpose of macroeconomic stabilization? Of structural adjustment? Of the transition to a market economy? Is it economic growth? Is it some combination of "efficiency" and "equity", and if so, what kind of "efficiency" and what kind of "equity"? All too often, macroeconomic policies are formulated on the basis of some sort of presumed good rather than in terms of some explicit, clearly articulated objective. This is ironic, because economics is precisely the social science with the firmest foundation in maximization. In microeconomics, it is customary to model existing systems and conduct policy analyses with single objectives (typically, profit in the case of firms, and utility in the case of workers). Why, when it comes to policy formulation, are we not equally explicit about what we are seeking?

Decent work provides an opportunity to be very specific about the policy goals of an organization, a nation or the concerned world community. Maximizing a combination of the quantity and quality of work is like maximizing the utility arising from a person's access to goods and leisure. The goal is to move the frontier further into the positive quadrant, from a curve like $\mathrm{D}$ in figure 1 to one like $\mathrm{D}^{1}$. If both components can be enhanced by some sort of policy action, such an action is assuredly beneficial. (Of course, the costs of the policy action must be given equal weight.) If not, then confronting trade-offs along the highest attainable frontier is preferable to facing these trade-offs along a dominated path. ${ }^{1}$

Intertemporal considerations can easily be accommodated. Whatever is said about decent work at one point in time can also be said about decent work at various points in time. Thus, the objective may be thought to be the attainment of decent work today and tomorrow for as many members of the labour force as possible. Once the dependence of tomorrow's conditions on today's is modelled, standard methods of multi-period analysis with discounting may be brought to bear.

${ }^{1}$ If one curve lies entirely outside the other, so that for any given amount of one good, more of the other is available, then the curve that lies outside is said to be "dominant" and the one that lies inside is said to be "dominated". 


\section{Policies for decent work}

Turning now to policies for decent work, a number of instruments exist with which to bring it about. There are three main sets of policy instruments within the labour market, as well as a number of others that impinge upon the labour market.

Labour demand policies are aimed at increasing the number of workers firms wish to employ. The demand for labour is derived from the supply of and demand for product. To the extent that more of a country's products can be sold to those who have the ability to pay (be they in that country or elsewhere), more of the country's workers can be employed in producing those products. Labour demand can be facilitated by employment-friendly labour market policies and a sound business environment, including secure property rights, enforcement of contracts, sound corporate governance, suitable competition policy, financial regulation, specifically tailored institutional design, attraction of foreign direct investment and retention of domestic capital, and appropriate sequencing and timing of policy reforms.

A second area for labour market policy intervention is labour supply. Labour supply includes not only the number of people available for work but also the quality of the human capital that these workers bring to the labour market. The more a country's workers present the skills needed for today's globalized economy, the better the country's chances of attaining its decent work goals. Elements of labour supply policy include education, training and other types of skills development.

And third, there are policies concerning labour market functioning. The most important of these is wage determination - in particular, whether wages are set by supply and demand or by some other set of forces. But other factors are important too: the availability of information on job vacancies and jobseekers, the ability of companies to engage workers as needed and to retrench them when not needed, and the ease or difficulty with which workers can move to where the jobs are. Many countries have engaged in active labour market policies to a greater or lesser degree, and the ILO has considerable institutional expertise on such policies (e.g. ILO, 1997; ILO, 1998).

In addition, policies for decent work also involve decisions sometimes regarded as lying outside the purview of labour market policy per $s e$. Labour demand reflects a nation's trade orientation, industrial strategy and commercial policies, all of which can be influenced by the decent work agenda. Labour supply policies involve not only human capital development, but also the fuller utilization of existing human capital through anti-discrimination policies and kindred policies such as childcare and health care. Policies affecting labour market functioning can lead into related areas such as housing market policies, pension policies and the role of the welfare state. What unites these additional 
policy areas is that they all have implications for the labour market even though they are not oriented towards the labour market per se. Opportunities for decent work are affected, for better or for worse, by policies in these other areas.

\section{Making choices within the decent work framework}

The decent work objective - specifically, maximizing the decent work frontier - has implications for both what action to take and what action to avoid.

First, what action to take. Implicit in the decent work initiative is the question, promote decent work for whom? This is only partly a question of how to make the biggest difference in employment terms. There is also the issue of how to make the biggest difference in welfare terms. Here, there can be little doubt: the priority for decent work must be to help the poorest workers of the world. Some of the poorest workers of the world live in the richer countries, but most do not. It follows that efforts are required at the global level to help those whose economic well-being is lowest and who therefore have the greatest need. International transfers of resources on a much larger scale than at present are required in support of the decent work agenda. Here is an area where cooperation between the international agencies - the ILO, the World Bank, the regional development banks and the bilateral donors - can make a profound difference.

At the same time, it is a harsh truth that it may be so hard to help some of the poorest workers in the poorest countries that efforts have to be concentrated on others. For example, little can be done to help an elderly illiterate farmer living in a remote village get a better job, and it may be that the limited resources available under decent work may have to be channelled to others. This is not meant to exclude such people from international aid efforts. It is precisely because these people cannot be helped through employment programmes that other types of assistance are needed.

Maximizing the decent work frontier has other implications for what not to do. Some well-intentioned labour market policies can actually hamper the decent work effort conceived as the employmentearnings frontier. For example, many countries' labour policies restrict or even prohibit dismissal of workers. In the short run, bans on dismissals keep workers in jobs, raising employment. But in the longer run, the employment effect may be just the opposite: because workers cannot be dismissed if they are no longer needed or if their performance is not up to standard, firms may choose not to hire them in the first place. Employment suffers - and so does decent work.

Another action to avoid is to devote scarce resources to those who could otherwise help themselves, or to activities that help the recipients 
without adding to overall employment. Take the case of public employment services, or labour exchanges. These increase employment only to the extent that unemployment is frictional, and as a result jobs remain unfilled because firms and workers have difficulties matching up with one another. But if this is not the reason for the unemployment and if employment is limited by deficient aggregate demand, improved job information will simply reallocate a fixed number of jobs among different individuals, without raising the total number of persons employed. What decent work helps do, then, is guide the allocation of resources towards the activities that contribute most to increasing jobs and/or earnings.

The attainment of decent work is constrained not only by policy choices but also by the limitations imposed by resource scarcity. More resources for decent work might be sought from a variety of sources: reallocation of domestic budgets, retention of domestic investment, attraction of foreign direct investment, increased aid flows and debt relief. However, once these resource channels are exhausted, policymakers have no option but to confront the hard choices that remain.

Not everyone will find this easy to do. Why?

1. Some refuse to accept the terms of the trade-off: "I want more of this and that", they say. Let us agree: if it is possible to have more of both quantity of work and quality of work, then by all means let us do so. It is precisely when more of both cannot be had that a choice must be made about where to locate oneself along the decent work frontier.

2. Some reject any attempt at reductionism. Even if decent work is conceived of in the way that the ILO has suggested (comprising full employment, improved levels of socio-economic security, universal respect for fundamental principles and rights at work, and the strengthening of social dialogue), other elements of good jobs are excluded: not only earnings but also joy, status, social participation and job safety, among others. To decide to highlight some things is to decide not to highlight others.

3. Given a limited number of foci, some favour giving equal weight to all of them. "If four things are to be done," they say, "let's use 25 per cent of our budget on each." This is unwise because only rarely are the four foci equally important. The greatest social return may come from using a disproportionate amount of the available resources on only one or two of the possible activities. In conditions of widespread food inadequacy, for instance, feeding the hungry surely takes precedence over social dialogue and secure employment.

4. Finally, there are those who find the entire context within which such choices are made to be reprehensible. "The world needs revolutionary change," these people say. On the off chance that the 
ILO might not be able to bring about a social revolution, working for social and economic justice in an unjust world with the very limited means available is the only remaining option.

To those voicing such objections, the suitable response is that opportunity costs must be confronted. Given a binding resource constraint, doing more in one area means doing less in another. Realism demands that such trade-offs be confronted. So, too, does the heartfelt desire to better the economic position of the disadvantaged people of the world. Wishful thinking is needed, but is no substitute for hard thinking.

\section{Summarizing the elements of an integrated approach}

Putting these various pieces together, the stated strategic objectives of decent work are to achieve full employment, improved levels of socio-economic security, universal respect for fundamental principles and rights at work, and the strengthening of social dialogue. Social objectives are indistinguishable from economic ones.

An integrated welfare economic framework consists of specifying an objective, policy instruments, constraints and a causal model. The central objective suggested here is decent work today and tomorrow for as many people as possible. The constraints are the available resources, which may be severely limited. The available instruments are the allocation of existing resources among alternative uses. The policy instruments include labour demand, labour supply and labour market functioning. Models are needed to show how the quantity and quality of work would respond to various policy interventions.

In short, decent work can be operationalized in a way that prescribes what countries should and should not do; it is a useful organizing framework for national and international policy choices.

What has just been described is a very complex and ambitious set of considerations. At the same time, by calling attention to certain key factors and excluding other less central ones, an integrated approach has been set forth. Two other aspects of decent work will now be considered: assessing the effects of economic growth on decent work and outlining the structure of subsequent country reviews.

\section{Assessing the effects of economic growth on decent work}

\section{Theoretical links between economic growth and decent work}

What role can economic growth play in promoting decent work? In the absence of data, two very different, even contradictory, perspectives are brought to bear. 
On the one hand, the growth optimists presume a healthy complementarity between macroeconomic growth and improved employment conditions. According to this line of thinking, economic growth drives up the demand for labour, which increases employment and raises real wages. In turn, when labour is reallocated to areas of greatest need, productivity is increased and output raised. A virtuous circle of continuous growth and labour market improvements is thereby realized. Workers benefit by participating in an ever-richer economy.

On the other side is a decidedly more pessimistic position. Some of those favouring decent work are deeply sceptical about the potential for economic growth to contribute to its attainment. According to this line of argument, in today's highly competitive global economy, the drive to retain existing markets and penetrate new ones is hampered by rising labour costs. Thus, it is said, economic growth can take place if and only if labour costs are held down. On this view, economic growth is antithetical to improvements in labour market conditions, because one can be achieved only at the expense of the other.

National policies have often been formulated on the assumption that economic growth is attained only by holding down the rate of growth of wages and other labour market conditions. At various times, some east Asian countries have experimented with repressive labour market policies in the hope of stimulating economic growth through lower labour costs (Fields and Wan, 1989). Working through the National Wages Council, Singapore tried direct wage repression. This policy was abandoned at the request of employers when it became clear that economic growth was being choked by labour shortages. The Republic of Korea openly repressed organized labour until 1987, in large part because of the belief that strong unions would raise wages, which would hamper the country's international competitiveness. Even now, the more militant trade union federation, the Korean Confederation of Trade Unions, is denied full legitimacy by the Government.

A simple diagram can illustrate the problems with wage repression (holding wages below market-clearing levels) and labour repression (preventing the free operation of unions in the labour market). Figure 2 a presents the diagram of an aggregate labour market with a standard upward-sloping labour supply curve (S) and a standard downwardsloping labour demand curve (D). Under conditions of free market wage determination, the labour market would clear at a wage level of $\mathrm{W}^{*}$. At this wage, $\mathrm{L}^{*}$ workers would be employed.

What happens if businesses are now able to penetrate new markets? Additional labour is needed for production, which shifts the demand for labour curve rightward. As shown in figure $2 b$, wages would rise as output rises. These wage increases should be favoured not only by workers but also by employers - if wages did not rise, less labour 
Figure 2a. Market wage determination maximizes employment and output, given $\mathrm{S}$ and $\mathrm{D}$

S

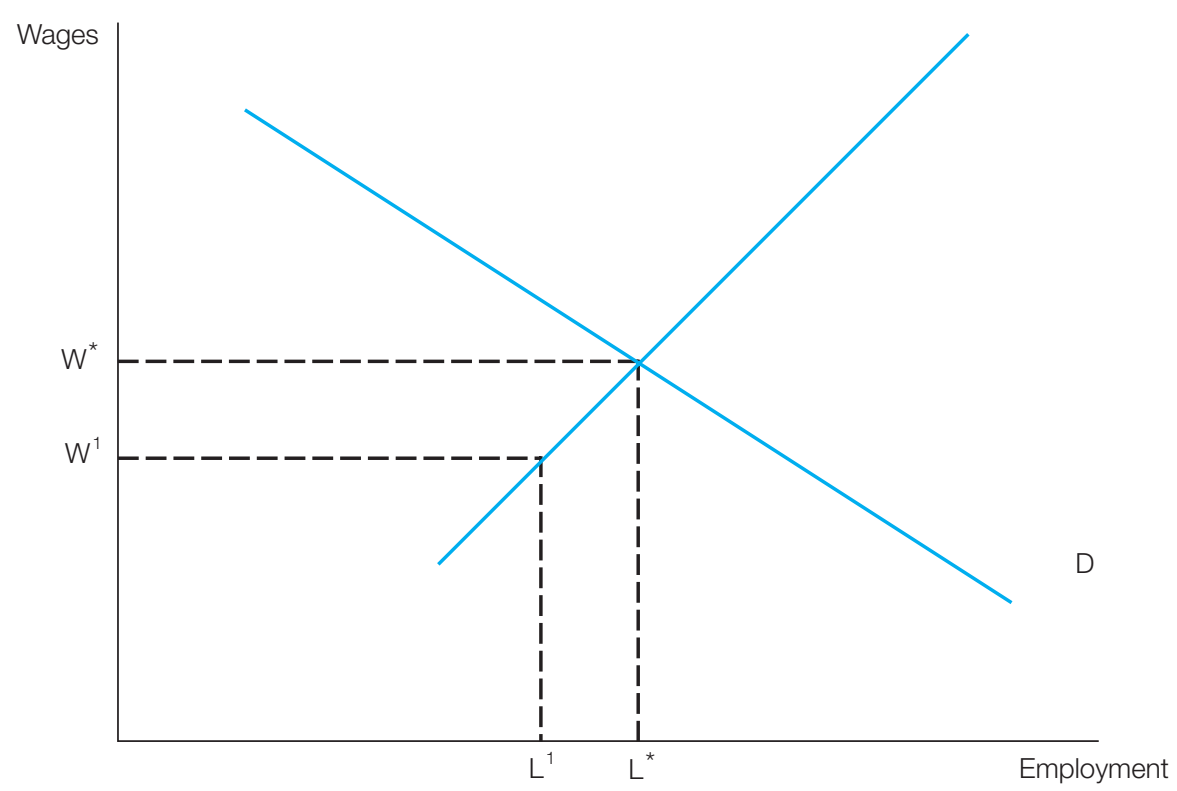

Figure $2 b$. A shift of labour demand increases employment and wages, given $\mathrm{S}$

S

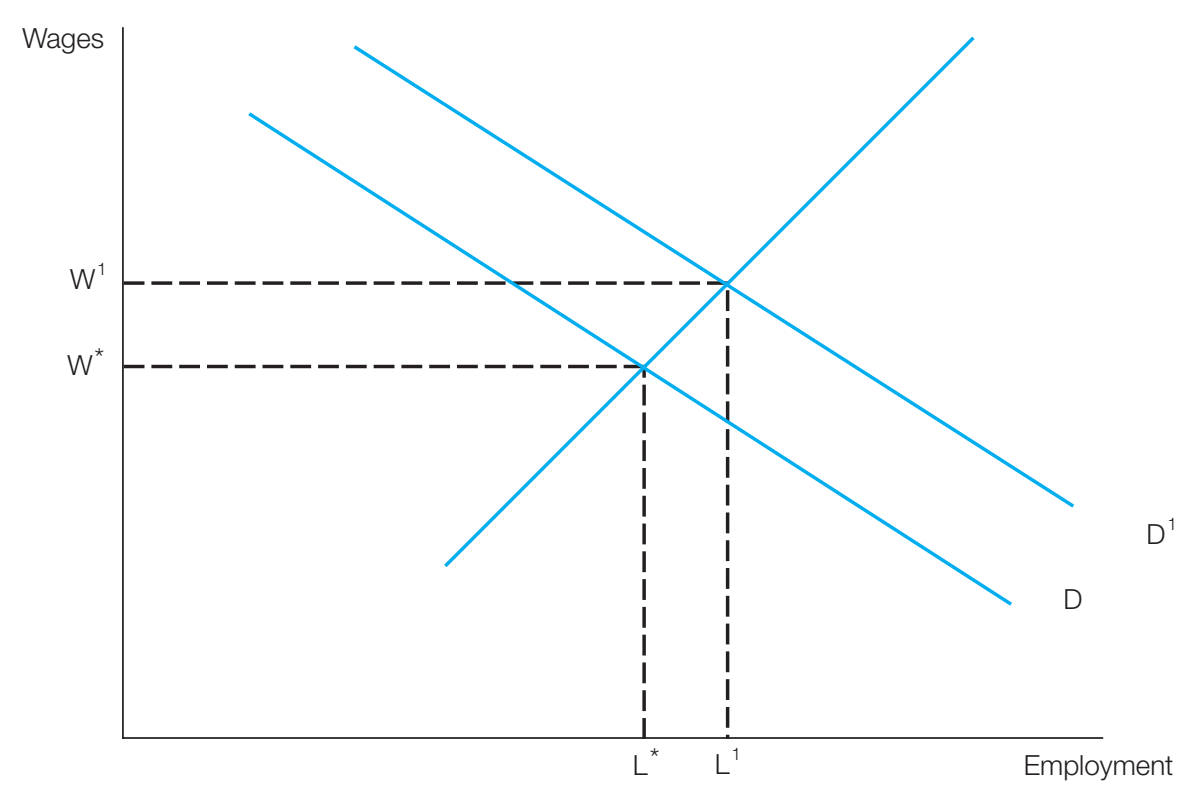


would be available and output growth would be stifled. In the diagram, employment is lower, and so, too, is output, at $\mathrm{W}^{*}$ than at $\mathrm{W}^{1}$.

From the theory just presented, it can be concluded that a healthy complementarity is expected to exist between output growth on the one hand and improvements in employment and earnings on the other. How does empirical evidence accord with this theory?

\section{Empirical evidence on economic growth and decent work}

The key question on the link between decent work and economic growth is this: in today's globalized world, does economic growth contribute to or detract from the attainment of decent work? In particular, what has been the impact of economic growth (or lack thereof) on employment and unemployment, job mix, earnings levels, poverty and inequality?

The ILO has made important contributions to knowledge in this area over the years. The most important continuing publication is its biennial World Employment Report. The 1996-97 report, for example, contains a section on growth of employment and unemployment, as well as employment and real earnings in manufacturing, in a wide range of countries (ILO, 1997). The 1998-99 report also analyses policies and programmes for improving employment opportunities for women, informal-sector workers and members of vulnerable groups (ILO, 1998). The most recent report focuses on employment changes due to the growth of information and communication technologies and the consequent national and global inequalities (ILO, 2001b). Unfortunately, no economy-wide earnings data are presented. So for poverty, one must perforce turn to other sources.

In a series of papers (most recently: Fields (1999); Fields and Bagg (forthcoming)), I have dealt with this issue. According to these data, Hong Kong, the Republic of Korea, Singapore, and Taiwan (China) registered the highest growth rates in the world. Real earnings increased by a factor of four in Hong Kong in 30 years, by a factor of six in the Republic of Korea in 25 years, and by a factor of eight in Taiwan in 30 years - in each case, with unemployment rates of 2 to 4 per cent per annum. Contrariwise, in six Latin American economies which suffered from (at best) slow economic growth and, in a number of cases, macroeconomic decline, labour market conditions worsened substantially - in some cases, this manifested itself in distressingly high unemployment rates (14 per cent in Chile, 13 per cent in Venezuela) and in other cases in shocking declines in real labour earnings (20 per cent in Mexico, 32 per cent in Brazil, 47 per cent in Venezuela and 58 per cent in Bolivia).

The World Development Report 1995 reports similar patterns (World Bank, 1995). Rapid growth in output per worker in countries 
such as China, Indonesia and the Republic of Korea is shown to have produced rapid rises in the labour incomes of wage workers and the self-employed. On the other hand, in sub-Saharan Africa, Latin Amerrica, the Middle East and South Asia, economic growth was slower, as was wage growth. Looking specifically at the industrial sector, the World Bank reports that real wages rose by 175 per cent in East Asia and the Pacific, by 25 per cent in the Middle East and North Africa, by 10 per cent in Latin America and the Caribbean, and by nothing at all in sub-Saharan Africa - mapping closely the aggregate growth rates in these various regions.

Another source of information is an OECD study, which examines labour market changes in that organization's five newest member countries (the Czech Republic, Hungary, Republic of Korea, Mexico and Poland) from 1989 to 1999 (OECD, 2000c). These data show a very high rate of real GDP growth in the Republic of Korea, a lesser rate in Mexico, a slow rate in Poland, a decline followed by a recovery back to the original level in Hungary and a decline but not yet followed by a full recovery in the Czech Republic. Data on employment and unemployment show modest growth of employment of both men and women in the Republic of Korea, and shrinking employment of both women and men in Poland, Hungary and the Czech Republic - a pattern consistent with employment growth accompanying GDP growth (and likewise for non-growth). In all of these economies, the sectoral composition of employment shifted away from agriculture and industry and in favour of services. No data are presented on changes in earnings in the OECD study.

Studies of individual countries also abound. One such is work by Freeman (2001) on the United States. He shows that in years of economic growth, both the unemployment rate and the poverty rate fell. On the other hand, in all recession years, the unemployment rate rose, and in all but one, the poverty rate rose as well. Freeman draws two conclusions: first, that wages and employment have both risen among the poverty-prone during times of economic expansion; but, second, that "the reduction in poverty and improvement in behaviour that accompanied the 1990s boom do not mean that the United States can rely exclusively or even primarily on economic growth toward the goal of ending poverty... Social policy, public or private, will be needed..." (ibid., p. 25).

Despite what has been learned, this review reveals a disturbing paucity of recent data on the question of whether economic growth contributes to or detracts from the attainment of decent work - only the OECD study uses data for the 1990s. Clearly, gathering a series of up-to-date information is a prime topic for further research. In fact, studies are now under way at the ILO, the International Institute for Labour Studies, the International Finance Corporation and the United 
Kingdom's Department for International Development and the results of these and other investigations are awaited.

\section{Summary: How economic growth contributes to decent work}

This section has reviewed evidence pertinent to the debate about whether economic growth contributes to or impedes the attainment of decent work objectives. The available evidence, limited though it is, points conclusively in the direction of complementarity - that is, economic growth causes fuller employment and higher earnings levels. Opponents of this view typically present anecdotes - case studies of groups of people who have not been helped, or who have ever been hurt, by economic growth. The failure of economic growth to reach everyone is a fact that should not be overlooked. At the same time, though, to conclude from such anecdotes that economic growth leads generally to a worsening of employment conditions is a ludicrous and dangerous misreading of the evidence. Such reports are journalism, not social science, and should never be confused with research.

The explanation comes down to labour supply and labour demand. The World Bank's World Development Report 1995: Workers in an integrating world explains it thus:

Within occupations, pay differences across countries reflect the average level of economy-wide productivity. If a bus driver in Seoul earns three times as much as a bus driver in Bombay, it is not because the Korean is three times better at driving a bus. Instead, the higher level of labour productivity in the Korean economy overall, and hence the higher level of incomes there, mean that, on the one hand, the bus drivers must be paid enough to persuade them to drive a bus rather than do something else for a living, while on the other, consumers in Seoul are willing and able to pay more for a bus ride than consumers in Bombay (World Bank, 1995, p. 12)

This section concludes with an observation on a fact so obvious that it is often not seen. The explanation in the preceding paragraph relies on equilibrium analysis taking the separation of nation-states as given. For this to be an equilibrium, Bombay bus drivers must be prevented from becoming Seoul bus drivers (or Seoul bus drivers from becoming Geneva bus drivers). This is exactly what international migration controls in the richer countries are meant to achieve. One of the great unmentionables in discussions of international labour rights and standards, under decent work or anything else, is the freeing-up of opportunities for people to move across national boundaries in pursuit of better work.

\section{Outlining the structure of subsequent country reviews}

The ILO is planning to conduct various country reviews, which will assess progress in achieving decent work objectives and evaluate 
policies for advancing the decent work agenda. Furthermore, the ILO recently announced a major initiative aimed at measuring decent work with statistical indicators (Anker et al., 2002; for a condensed version of this working paper, see pp. 147-177 of this issue of the Review). In this section, I shall sketch my own views on what these reviews might highlight and what statistical indicators I would regard as the most meaningful.

First, on the question of progress, the variables discussed earlier are the main ones, namely, what has been the macroeconomic context. Has the economy been growing or declining? At what rate? What have been the key sectors in which changes have taken place? What are the main factors responsible for these changes?

The next question is, how have labour market conditions changed, economy-wide and for particular groups? The first set of variables concerned employment and unemployment. How many people are working? What has happened to the unemployment rate? (The two are not mirror images of one another because of possible changes in labour force participation due to labour force entries and exits, immigration, changes in school-leaving behaviour and retirements.) The second set of variables is job mix. Here, the concern is not the fact of employment but also the kinds of employment people are in: by industry (manufacturing, services, agriculture, etc.), occupation (professional, clerical and sales, manual, etc.), occupational position (wage employment, selfemployment, casual employment, unpaid family work) and educational level. The third set of variables is earnings levels. Here, the aim is to establish how many people are earning how much, overall and for key disaggregations: by sex, sector, geographic location and so on. Once these data have been collected, it would be known for that country by how much conditions in labour markets have been improving or worsening, and for whom.

Following this review of the evidence on changing macroeconomic events and labour market conditions, the country reviews should turn to the issue of policy variables. What are the key aspects of a country's policies that help one understand the observed changes? Here, the policy review might usefully be categorized into three types of policies. Labour supply policies address two sets of issues: how many people are available to work, and what skills and characteristics they bring to the labour market when they do offer their labour. Labour demand policies then get at a range of factors determining the position of the labour demand curve: trade and industrialization strategies, commercial policies, investment climate, business environment and the like. Finally, policies with regard to labour market functioning help one understand why conditions are as they are. This heading would include wagesetting mechanisms, institutional regulations, flexibilities and rigidities in the market for labour services, the presence or absence of active 
labour market policies and other affiliated policies which have a bearing on the workings of labour markets.

Together, these data would afford the possibility of answering three related questions about the attainment of decent work in a given country. What is the macroeconomic context within which the country is operating? What is the evidence on key variables that form part of the decent work agenda? And what are the main policy variables helping to explain the rate of progress or lack thereof? Focused reviews of this type would not only aid understanding of what has been done but would also orient attention towards what could be done to improve the quantity and quality of employment in a particular country context.

\section{Conclusions}

The ILO's decent work initiative is a way of focusing the efforts of individual countries and of the international community on one of the principal means of achieving development: creating more and better jobs. This article has made four main points about ways of advancing the decent work agenda.

First, an operationalization of decent work has been suggested: jobs, at acceptable earnings levels, in which core labour standards are honoured. The key dimensions of decent work are employment and earnings. Under a given set of conditions, pursuing one of these goals may conflict with the pursuit of the other. As long as the labour demand curve remains stationary, a trade-off is inevitable between higher wages for those now employed and increased employment for others.

The second contribution of this article has been to move towards an integrated framework for analysing economic and social objectives and policies. This can be achieved by adopting a welfare economics perspective, which consists of specifying an objective, policy instruments, constraints and a causal model. The objective that has been suggested is the highest level of decent work now and in the future. The policy instruments are, in the first instance, labour demand, labour supply and labour market functioning policies, both direct and indirect ones. The constraints are the available resources. Causal models inform on how various components of decent work would respond to various policy interventions and various decisions about how to allocate scarce resources among alternative uses.

Third, this article has reviewed the evidence on decent work and economic growth. Contrary to the fears of some, the available evidence, limited though it is, indicates a pronounced complementarity between the two. Economic growth does not come at the expense of decent work, or vice versa.

Finally, a structure has been suggested for reviews of experience and policies at the country level. Given the macroeconomic context, the 
three key variables for assessing progress towards decent work are changes in employment and unemployment, job mix and earnings levels, overall and for various population groups. The three major policy variables to include in such reviews are labour supply policies, labour demand policies and policies with respect to labour market functioning.

Looking ahead, two major research needs stand out: first, much more aggregate information of the type used in the section on how labour market conditions have changed in various countries' experience of growth (or non-growth), especially over the past five or ten years. Second, country reviews of the type discussed are needed for a broad range of countries.

By carrying forward the decent work policy and research agendas, the ILO can re-establish its prominence among the development policy agencies. For the hundreds of million working people in the world who have not yet attained decent and adequate jobs, this would be a very welcome step forward indeed.

\section{References}

Anker, Richard; Chernyshev, Igor; Egger, Philippe; Mehran, Farhad; Ritter, Joseph. 2002. Measuring decent work with statistical indicators. Policy Integration Department/ Statistical Development and Analysis Group (INTEGRATION/SDA). Geneva, ILO, Oct.

Fields, Gary S. 1999. "Employment generation and poverty alleviation in developing economies", in Ulrich Hiemenz (ed.): Growth and competition in the New Global Economy, Paris, OECD, pp. 91-112.

-; Bagg, Walter S. Forthcoming. "Long-term economic mobility and the private sector in developing countries", in Gary S. Fields and Guy Pfeffermann (eds.): Pathways out of poverty, Boston, MA, Kluwer Academic Publishers.

-; Wan (Jr.), Henry Y. 1989. "Wage-setting institutions and economic growth", in World Development (Kidlington, Oxford), Vol. 17, No. 9 (Sep.), pp. 1471-1484.

Freeman, Richard. 2001. The rising tide lifts... NBER Working Paper No. 8155. Cambridge, MA, National Bureau of Economic Research. Downloadable at http://www.nber.org/ papers/w8155 [visited 27 June 2003].

Hamermesh, Daniel. 1993. Labor demand. Princeton, NJ, Princeton University Press.

ILO. 2003. Global employment trends. Geneva.

-. 2001a. Reducing the decent work deficit - A global challenge. Report of the DirectorGeneral to the 89th Session of the International Labour Conference. Geneva.

-. 2001b. World Employment Report 2001: Life at work in the information economy. Geneva.

-.2000a. Report of the Working Party on the Social Dimension of Globalization. GB.279/16, November. ILO Governing Body, 279th Session. Geneva.

$-.2000 \mathrm{~b}$. "Employment-intensive growth in the context of globalization". Speech by the Director-General of the ILO to a public meeting on the Social Summit+5, organized by the Swiss Agency for Development and Cooperation (SDC), in Bern,11 May 2000. Downloadable at http://www.ilo.org/public/english/bureau/dgo/speeches/somavia/ 2000/bern.htm [visited 2 July 2003].

-. 1999. Decent work. Report of the Director-General to the 87th Session of the International Labour Conference. Geneva.

-.1998. World Employment Report 1998/99: Employability in the global economy. Geneva. 
-.1997. World Employment Report 1996/97: National policies in a global context. Geneva. Lipton, Michael. 1998. Successes in anti-poverty. Geneva, ILO.

Organisation for Economic Co-operation and Development (OECD). 2000a. OECD Guidelines for multinational enterprises: Global instruments for corporate responsibility. Paris.

- .2000b. International trade and core labour standards. Paris.

-. 2000c. "Recent labour market developments and prospects: Special focus on the evolution of employment in the new OECD Member countries", in Employment Outlook 2000 (Paris), pp. 11-30. Downloadable at http://www.oecd.org/pdf/M00028000/ M00028067.pdf [visited 1 July 2003].

- .1996. Trade, employment and labour standards: A study of core workers' rights and international trade. Paris.

Samuelson, Paul. 1964. Economics. New York, NY, McGraw Hill.

United Nations. 2003. 2003 Economic and Social Council. Downloadable at http:// www.un.org/esa/coordination/ecosoc/overview.htm [visited 26 June 2003].

United States Congress. 2002. Trade Act of 2002. Downloadable at http://www.tpa.gov/TPAtext.htm [visited 19 August 2003].

World Bank. 2000. World Development Report 2000/2001: Attacking poverty. Washington, DC.

- 1995. World Development Report 1995: Workers in an integrating world. Washington, DC.

World Trade Organization (WTO). 2003. Trade and labour standards: Subject of intense debate. Downloadable at http://www.wto.org/english/thewto_e/minist_e/min99_e/ english/about_e/18lab_e.htm [visited 27 June 2003].

- 1997. Focus (Geneva), Newsletter of the WTO, No. 15, Jan. Downloadable at http:// www.wto.org/english/res_e/focus_e/focus_e.htm [visited 27 June 2003]. 